\title{
Discourses Within and About Social Work
}

Irene Levin, Professor, Oslo University College, Norway 
Is it possible to gain a fuller understanding of social work by using the concept of discourse? In this article I examine social work as a discursive practice. My aim here is to discover whether this kind of discursive framing may add to our understanding of the discipline of social work. Discourse ${ }^{11}$, as I understand it, is a social phenomenon based upon a social and a cultural relationship serving as a foundation for making shared assessments (Magnusson 1998, Fook, 2002). As used here, discourse refers to a more extensive social phenomenon both formed and spread by language and which involves the contributions of many people through time (Magnusson, 1998:182). When this is related to a discipline such as social work, discourse also involves issues involving competency as linked to a position or status.

When making use of discourse analysis, this requires shifting one's attention away from a focus on the characteristics of individuals, mechanisms and structures and towards a focus on language, interaction and processes. This shift directs attention to the social field between the individual and the society. According to Magnusson (1998), it is precisely through discourses that the individual both transforms her experiences into her identity as well as creates herself in interaction with others. Given this framing, it therefore should be interesting to see how and to what degree social workers shape their practice and with that, their identities, through discourses of social work.

At the same time, there exist discourses about social work. Here I am thinking specifically about the low status of social work not only within academe, but also within society at large. Most likely, there exists a reciprocal relationship between these two spheres and the often negative attributions attached to social work in the academy and elsewhere. These kinds of assessments are, however, not unequivocal. In many circles and sectors of society, social work represents progressive ideas - especially when the discipline is seen as fighting for the rights of the weakest members of society as well as struggling and demonstrating against injustice, intolerance and other destructive forces in society.

Nonetheless, everyday speech contains numerous examples referring to social workers as 'wishywashy do-gooders'. In the Norwegian language, it is not at all uncommon to hear social workers referred to as the 'mauve scarf and orthopedic shoe brigade'. These symbols clearly comprise a form of ridicule as well as a critique of the profession. Often, the terms social work and social worker are used in this way to symbolize something negative. Even when these words are simply said and not expanded upon, it is often unnecessary to ask what is meant by them. It is as if everyone knows what is being referred to and therefore it is not necessary to ask for explanations. A while ago, someone writing a letter to the editor in Norway's largest newspaper complained that the daily newscasts on Norwegian radio were becoming like social workers. It was unnecessary to expand on this since readers could be expected to know that the author of this complaint was indicating something about the superficiality and gullibility of the newscasters. This need not imply that every reader agreed with the writer, but that the writer was framing this letter within a current and commonly accepted discourse about social work and social workers in Norway.

\section{Boundaries of discourses}

The content of a phenomenon can often be best grasped by looking at its boundaries. The borders of a discourse often provide a clear indication of its connection to power and desire. A discourse is both that which illuminates and conceals desire, while a discourse is also about the object of desire that one struggles to attain.

According to Foucault (1993), there are three factors characterizing the boundaries of discourse. In the first place, there is the question of who and/or which agents are allowed to speak about any given case. There exist guides for filtering and sorting out who these speakers are to be. Secondly, there exist exclusionary mechanisms in the form of rules, prohibitions and 
dichotomies. And thirdly, there exist oppositions between that which is true and that which is false. In the following I will attempt to examine how these three sorting or classifying elements can have significance for the discipline of social work in relation to discourses about social work.

\section{Rules and prohibition}

Fahlgren (1999) has raised the question about how items and which persons are excluded from discourse. The answer, as already noted, is through rules and prohibitions (Foucault 1993). These determine what can be said as well as who may speak. Rules can be clearly expressed, but also can assume forms as procedures that more indirectly guide discourse in relation to existing power structures. In the case of social work, the rules are clear as to who is to advance the discipline. ${ }^{23}$ These often take the form of open and hidden agendas within academe, for example, as well as more general perceptions found in society about the position of social work. Within the academy, there exist distinct rules about who may express themselves in relation to certain questions as well as who may contribute to disciplinary developments. These are persons in possession of well-defined academic qualifications preferably doctorates - and whose disciplinary activities primarily involve research. These persons express themselves about the field through direct or indirect discussions as well as contribute to disciplinary development through writings in journals and books.

\section{Dichotomies}

Exclusion can also occur through what Foucault described as dividing practices involving oppositions and dichotomies. As an example of this, Foucault (1993) used the division made between madness and reason by Western science. In this division, reason achieved its status and significance through a process by which madness was found to be reprehensible. This example, in turn, can be related to social work's main concern with the socially excluded. In one sense, social work gains its legitimacy through a process whereby it becomes the domain of the normal since its clients are defined as being abnormal. By virtue of being the object of social work practice, these clients are thus defined as being outside the so-called normal. ${ }^{37}$

Another dichotomizing process contributing to the exclusion of social work and serving also to hinder participation in the arena where disciplinary development takes place is the poorly defined relationship between theory and practice in the field. When practice is defined as the opposite of theory, it is assumed that it cannot be theorized about. Practice then can only be developed through practice. And in this respect, one can only add to the development of practice by a practical theory of practice.

However, if the dichotomy between practice and theory is abolished and one follows Kurt Lewin's (1944) well-known dictum that 'nothing is so practical as a good theory', one arrives at another result. The fact that the conceptual pair called 'theory and practice' exists in this form suggests an inbuilt opposition. If not, it would not be necessary to mention both. Instead, one could have said 'theory' and included within that 'practice' à la Lewin or one could have said 'practice' and meant theory as well, again according to Lewin. The question here is whether these concepts are mutually exclusive as in the form of a dichotomy or whether they complement each other.

\section{Truth and falsehood}

A third form of exclusionary practice discussed by Foucault involves oppositions between truths and falsehoods. During some periods, that which distinguishes what is true is the correctness or authority of the person producing the discourse, while at other times truth is determined by the content of the discourse. According to Foucault, the 'will' to establish truth $^{48}$ has been a major aim of science since the 1600s. Since that time, knowledge has been 
viewed as something that is both verifiable and useful (Foucault 1993). Today this discourse about truth has great institutional support and is what authorizes and legitimizes much of what takes place in our society. Truth has become a question of power.

Social work is dependent in many ways on such truth declarations involving the manner in which clients are diagnosed as criminal, unemployed, schizophrenic and so on. This provides both order and predictability (Levin 1996). On the other hand, this order and predictability may also function as an obstacle in the way of further development. Additionally, this contributes to creating a need for knowledge that is focused on ranking, diagnosing and other forms of ordering.

In this way, truth-seeking comes to dominate in one sense the aforementioned discursive exclusionary practices. In a way, it takes control over 'forbidden speech' and the discourse on madness. As Foucault (1993:14) puts it:

'the will to truth that so long has been forced upon us is such that the truth it seeks can not avoid disguising this will'.

Behind this will, Foucault sees both desire and power. Yet, the will to truth will not acknowledge this. Truth is given legitimacy by power relationships, but it would be called into question if desire and power were made visible. In this way, power and desire may be understood as the enemies of truth.

\section{Discourse about social work}

In this article, I argue that a discourse about social work exists, and that within this discourse is found a 'truth' about social work as a practical, rather than a theoretical, enterprise. Social work is placed and places itself outside what are understood as the academic rules for discussions about disciplinary development. Moreover, those within the field are not regarded as possessing the 'truthful' understanding of social work - this is reserved for others outside the field. This particular discourse has its own life and is maintained through a number of mechanisms. Central among these are those instances where individuals or society at large gain experiences casting doubt on dominant discourses about social workers. When this happens, these are defined as exceptions and, thus, it is possible to continue regarding social workers as incompetent. Similarly, when social work is carried out in a competent and beneficial manner, the professional background of the social worker is kept hidden or defined as having no importance. Good social work becomes in this way psychology. On the other hand, when it is carried out poorly, it becomes social work.

The discourse about social work must not be misunderstood as only concerning the views of others about social work and its practitioners. Social workers, too, are involved in this discourse. Like members of other oppressed groups, social workers are not immune to internalizing society's largely negative view of themselves and their occupation. It is clear that social workers exhibit this kind of ambivalence about themselves and their profession. The fact that social workers often internalize and integrate such views of themselves can also be related the analyses made about Jewish self-hate by Kurt Lewin (1944) in the 1930s as well as ethnic self-hate made by Jane Addams several decades earlier (1914). These kinds of phenomena often are expressed by social workers in their ambivalent views and feeling about their profession.

An example is found in the work of the committee which evaluated social work in Sweden in 1989. Though they arrived at a somewhat different conclusion, their report was written in much the same spirit. The committee maintained that social work ought to be more closely 
linked to the disciplines of psychology and sociology. Haluk Soydan (1993) claims that sociologists and other social scientists overestimate their abilities to solve theoretical and methodological problems while they underestimate social work's ability to develop its own theoretical and methodological identity. In line with this, Soydan further argues that contrary to popular opinion, social work does not lack traditions involving the history of ideas.

\section{Methods}

In this study, the population was the total number of social workers in Norway. The term social worker in this context was applied to both traditionally educated social workers and child protection workers.

The study was conducted in the end of 1990ies and the sample itself was comprised of 20 social workers from the Eastern part of Norway. They worked in both street-level bureaucracies and secondary institutions. These social workers were employed in municipal and rural social service agencies, child protection offices, child and adolescent psychiatric institutions, probation offices and adult psychiatric institutions. In total, ten different institutions were represented in the study. All of the informants had been employed at other work sites earlier. This meant that experiences from a number of other institutions were included in the narratives they related during the course of the interviews. In the course of the interview process, these 20 informants described more than 40 cases.

While some of the informants were relatively recent graduates of social work training institutions and had approximately two years of experience since graduation, other informants had worked as social workers for more than 30 years. Both sexes were represented in the sample in more or less the same proportion as found in the profession, i.e., 75 per cent women and 25 per cent men.

\section{A good case and a bad case}

To grasp how social workers go about reasoning as they work with cases is not a simple matter (Widerberg, 2001). They can easily experience questions asked of them as tests as to how clever they are in their professional work. This most probably can be said about studying many occupations. Nonetheless, this may be more problematic in social work since its practitioners represented a vulnerable group which has been the target of considerable criticism.

Therefore, I took as my point of departure the social worker's own definition of the situation (Thomas and Thomas, 1928). Informants were asked to make their own evaluations of working with cases: each informant was asked to describe what was good as well as what was bad in working with clients. In this way and in keeping with the theoretical and methodological orientation of the study, the social workers as informants could describe their own work with clients as well as the reasons why they evaluated some work as better than other.

In this way, the study design was divided into two parts. The first focused on those cases the social workers themselves felt had been successful. The social worker was asked to think of a case that she or he felt had handled well. Following this, the social worker was encouraged to talk about the case in such a way that the interviewer could take part in learning who the client was, what the problem concerned was and how the social worker felt she or he had contributed to solving the problem. The story was deemed finished once the interviewer felt that a picture of these three factors had been produced. This was then followed by an interview about the case and the informant's tackling of it. Here, the questions were aimed at making the actions as concrete as possible. In the course of this process focusing on what in fact was done, the interviewer was provided with a way of grasping the actions involved in working with the case. 
These, in turn, were then employed as the starting point of the analysis where a central goal was to understand what the informants wished to accomplish (the meaning creation aspect of behavior) as well as the background for why they acted in the way they did. Central to this analytic part were questions posed to the informants about what they felt in retrospect had been crucial in making the work successful. In addition, they were asked about the connections between this result and what they did in relation to clients.

Once this was completed, the informants were asked to describe cases where they felt they had been unsuccessful in working with clients. This part of the interview was constructed much like the first part. Initially, the informant was required to find a case illustrating this kind of problem. Then, she/he described who was involved, what the problem was and what attempts were made to solve it. The interview focused much on what the informant did or did not do in relation to the case. Again, the aim here was to make as concrete as possible what the informants did (the actions) rather than what they felt.

Each of the 20 informants provided two cases as well as the interview material drawn from discussion of the cases. These data constituted the point of departure for the analytic portion of the study. A central question here involved what characterized the relation between the analysis and the actions the social worker adjudged as successful. Likewise, a central question involved what characterized the relation between the analysis and the actions the social worker considered unsuccessful. A further question involved differences in the analytic work. If these differences were found, could they be related to other factors? Of special importance in this work was to identify the discourses within social work involved in the narrative descriptions and analyses produced by the informants.

\section{Results}

In the following section, I wish to concentrate on different aspects of the social worker's everyday life emerging in the course of examining the data. All of these aspects of everyday life are significant but are not presented here in any kind of hierarchic order. Initially, these may be understood as providing different dimensions of disciplinary discourses used by social workers. These are: the differential positioning of social workers, starting where clients are, processes of rejection and norm conflicts. These dimensions all constitute discourses in social work. In concluding the following discussion, I will focus on the relationship of social workers to contemporary discourses focusing on social work in society, i.e., discourses about social work.

\section{The differential positioning of the social worker}

In analyzing the data, one of the first things I found involved the different positions social workers assumed in carrying out their work. Prior to this discovery, I had assumed that social work tasks were carried out in two different arenas. One of these was the bureaucratic casework carried out by social workers in positions of authority, while the other involved work in therapeutic areas. I further assumed that these two areas of activity were mutually exclusive. In addition, I expected that this division would reflect the worksites employing the social workers. I assumed that case preparation, management and similar activities would take place in the street-level bureaucracies of social service offices and similar front-line institutions, while I assumed that therapeutic activities would occur in child, adolescent and adult psychiatric milieus. The probation services I also assumed would be much like these latter institutions.

However, when I began to search through the texts comprising much of the interview materials and tried to find what Eva Magnusson (1998) calls the 'voices' through which the social workers spoke, I discovered that there were many more categories than that of social casework versus therapy. 
Stated somewhat differently, it became clear that social workers had a range of subjectivities, positions or roles serving as the bases for their actions. In examining this great diversity, I will sort these into the three roles of authoritative practitioner, therapist and pedagogue. These, in turn, relate to three dominant discourses within social work. In one sense, these three represent classical divisions within social work. Within each of these, power is exercised both vertically and horizontally. What was striking, however, was that these three roles were present in all cases described and analyzed by the informants and were independent of whether or not the social worker worked at a front-line institution or not.

\section{Therapy in front-line agencies}

Thus, social workers working in front-line agencies not only performed case management tasks in the role of authority practitioners but they also carried out various forms of therapy.

A social worker at one social service office told about her work with a client that she regarded as successful because the client, a young man in his 20 s, ceased reacting with violence to every situation. In one of her first sessions with this man, she told him what she would do if he became violent with her. Making violence concrete was a constant theme throughout the many sessions where she worked with this young man. As she described it, her work with him that eventually stretched over many years was purely therapeutic.

'He has admitted to himself that his anger is fear and that he has experienced difficulties that put him into these kinds of situations. And then he thinks that his own life has now progressed, even though this has not been registered by those around him.'

Her task in relation to him as an authority figure was also very much a part of her work with him even though the work involving his social assistance claims were carried out by others at the agency. She helped him, for example, in applying for social security benefits as well as a dispensation from military service. In this part of the work, the client himself was an important contributor while the social worker assisted him in constructing these applications in a form where his arguments functioned in his own favor. He could not seek dispensation from the military because 'he would knock down the sergeant' as he put it. His reasons for seeking the dispensation had to be put into a context wherein they would be accepted. In working with these applications, the social worker assumed a pedagogic role. This was especially important since the client's seven years of schooling had not equipped him with the written skills necessary to apply to gain all the rights he was entitled to by law.

\section{To Begin Where The Client Is}

The phrase - 'begin where the client is' - nearly has the status of a key mantra in social work (Hoel and Rønnild, 2009, Saur, 2007). If one asks social workers why things worked out well for that particular case, they often answer that it was because 'they started where the client was'. In this study, the same pattern emerged.

We seem to prefer this as the basis for social work. Søren Kierkegaard, it seems, was much concerned with a similar situation more than 150 years ago. He maintained that if we really wished to help another person, then it was imperative that one:

'first and foremost be aware of where he was found, where he was and so begin there. This is the secret of all the arts of helping...In order really to help another human being, I must understand more than he does, but first and foremost understand that which he understands' (Kierkegaard, 1859). 
If I do not do this, it does not help that I possess more knowledge than the other person. Involved in this approach is the notion that by making myself humble in order to understand, I then can help by serving the other rather than commanding over them. He goes on:

'If you do not begin in this way with another person so that he can find relief in talking with you, then you can not help him. (Kierkegaard, 1859).

Writing for social workers, Helen Perlman (1957:30) spoke of starting where the client is. She felt that even though the social worker may have other ideas about which solutions are the correct ones, it is imperative to listen to what the client says and then to follow her/his lead. One comes no way at all, Perlman maintained, if one does not start there where the client finds herself/himself. Yet, in her presentation, it seems that she believes that the social worker possesses the truth.

Informants in this study often replied that the reason that the outcome of client work had been successful was because they had begun where the clients were. In registering these kinds of responses, I noticed that the informants lowered their voices and we (interviewer and informant) concurred in an understanding that 'of course - that is what it is all about'. This concurrence seemed to rule out any further questions. As long as one begins where the client is, then it is clear that one is doing a good job - or is at least on the right path.

But what exactly makes something 'start where the client is'? This seldom is made clear. Sometimes it is replaced with the phrase 'taking the client seriously' as Torhild Farsund Danbolt has suggested (1998) or the phrase 'come in position' (Kronstad, 2001). But here too one wonders what these phrases mean. When one states that it is important to begin where the client is, does this mean where the client is in an emotional sens? Or does it mean something in a more thematic sense as Perlman indicates? Or does it mean physical proximity?

\section{A case}

A social worker who had worked for many years in child and adolescent psychiatry described meeting a client who was both physically and psychically in need. He came to the clinic as a father of two children with whom he did not live.

'There sat a thin, young man on the sofa and the first words used when we began to speak were about the son, it was a 'problem'...' ' have a problem, I need help', he said. He then began to tell about his life with problems - that he had used lots of drugs, he had no money, no job, and was about to lose the place where he lived. And that he had not eaten in a long time. And was very depressed.

The social worker viewed this situation as so precarious that she went directly to the clinic's canteen and bought him some 'giant sandwiches with lots of good things inside' as well as something to drink.

'What was it that made you act that way?' I asked the social worker. She replied:

'It is only when you confront someone who is desperately hungry and who is knocked out by starvation that you have no doubts whatsoever about what you have to do'.

She admitted that she had never shown her concern in this way for a client in more than thirty years of working as a social worker. Following this episode, she attempted to have this client referred to adult psychiatry, but the waiting list was so long that this was of little help to him. The only thing offered him was a new period of waiting. She recalled that: 
'In the meantime, this man was really suffering. And this put me in a totally different situation than I had imagined when I began working with him'.

What then happened was that this man began in therapy with the social worker because there simply was no other form of help available for him.

In the course of therapy, the social worker also helped him contact the social service agency office. Her colleagues initiated contact with his two children and their mother and all four began in therapy with her. Not long afterwards, the man 'suddenly appeared one day... in work clothes'. He had gotten a job thanks to a friend. He managed to save enough money to take his children on a vacation to Spain. However, he still uses drugs though not when he is with his children and not so that it affects his work. She added:

'Afterwards I have thought that I would not have gotten such a good start in establishing contact with this man if it had not been for [the sandwiches]'.

In this case there were many things which seemed to have contributed to bringing about positive results. There were two therapists who shared the tasks, work was done to help the mother's nurturing as well as setting limits for the children. And the father was also helped to enhance his parenting skills with Marte Meo methods. In addition, the couple's relationship was worked with as well as the parent-child relationship involving such things as visitation. In retrospect, it seems clear that the situations of both the mother and the children were dependent upon how the father managed. The fact that the social worker succeeded in starting where the father really was in the true sense of the term seemed decisive in this case. Previously, he had failed to complete treatment with psychologists and physicians because he had no money to pay them or because he dared not show his face after failing to turn up for sessions.

\section{Rejection}

Initially, one thing impressing me in the course of the interviewing was the extent to which rejection of social workers was part of the social workers' activities. To be rejected by clients seemed to be an everyday occurrence for the social workers in my sample..$^{511}$

This was especially true of those who worked in frontline agencies. Among social workers employed in non-frontline agencies, rejection by clients was used to illustrate unsuccessful cases. But even social workers in frontline institutions commonly reported rejection taking place in successful cases (Levin, 2004).

Rejection assumed many forms. It could be when clients did not keep appointments. To be required to request repeatedly for clients to come to meetings was usual - it was a part of the social worker's everyday experience (Smith, 1987). Rejection could also take the form of contacts with clients who greeted social workers' with such invectives as, 'you damn bitch' or 'every time I hear your voice, I get a bad feeling inside'.

A third form of rejection involved lack of response by clients to the interventions by social workers. In all these areas, rejection stemmed from clients. However, the extent to which these acts were experienced as rejections depended upon how the individual social worker defined the situation (Thomas and Thomas, 1928). If she or he defines the situation so that not much can be expected from a particular client, the experience of being rejected does not become a major setback.

One of the informants reported that those cases where she felt successful were those where she had decided that she would not let the clients manage to reject her. She told that sometimes she felt a special kind of gut feeling and said to herself: 
'damn it, here I'm not going to give up! I'm going to get a hold of some of the resources of this person (the client) recognizes or manages to be keep under wraps. That is going to be my motivator. They aren't going to get rid of me... Now she isn't going to disappear for me'.

This experienced social worker knows both her own self and the system so well that she is aware of all the pitfalls. And she says to herself that she must watch out so that rejection can not occur. She was especially concerned with cases where treatment had to include clear prophylactic elements, for example, if the case involved a mother with small children. By helping the mother, in all probability she also helped the children.

Yet the social workers that I interviewed also reported being rejected by colleagues and other bureaucratic agencies. Here, rejection was of a different sort than that which the social workers experienced in working with clients. While in client work, the social worker was the person having power; in contact with colleagues and other agencies, the power was often in the hands of others and rejection then became experienced by social workers as a vertical disparagement.

Rejection in these instances was not defined solely by social workers in terms of not receiving approval for all aspects of their work. For example, if a higher authority did not accept the social worker's definition of the situation as presented in the case documents, this was not necessarily perceived as rejection. The fact that social workers did not always experience disapproval of their work by higher authorities as a form of rejection may be related to their acceptance of these authorities and their ability to see their own work through the eyes of these authorities.

If a local or provincial authority stated that the background material presented by the social worker was not good enough, this was often accepted as 'not being good enough'. However, sometimes being refused by a higher authority could be experienced as a rejection or a vertical disparagement.

\section{Rejection as feeling}

Rejection, however, involves not only actions carried out by someone with whom the social worker has a relationship. Rejection is also a feeling. In addition, it is an expression of a relation involving power versus impotence in any given situation. To be rejected or disparaged means to have power taken from oneself in a situation. In relation to clients, the social worker possesses power - at least at the start of their meetings. By rejecting the social worker, the client assumes power. Yet, the social worker cannot progress until the client has accepted the social worker as the one in possession of power. Temporarily, at least, the client must relinquish her/his power so that the social worker can use it to aid the client to help herself/himself.

But when rejection takes place in relation to colleagues, the situation for the social worker becomes a different one. Here, one can speak of power versus impotence. In a number of occupational hierarchies, the social worker often is positioned lower than other groups such as, psychologists and psychiatrists, for example. When the social worker is required to get a diagnosis from a psychologist or physician, this reinforces the disciplinary processes of the occupational hierarchy. Often, social workers diagnose, even though their occupational group cannot legitimately do this. The laws and norms do not allow this to be done. The social worker must therefore have her or his diagnosis confirmed by a psychologist or physician since this is required by authorities such as the provincial child protection agency. By being constantly required to accept this arrangement, social workers in child protection and at social service agencies are required also to accept their own subordination. If one does not accept this, one 
cannot be employed at certain workplaces - and this is an alternative chosen by a good many social workers. On the other hand, one can accept this arrangement with 'a smiling face' as a number of informants described it. As they put it, 'this we do in order to please the system, but we know what we can do and so we let the others believe that they know best what to do'. Here the rationale described by the informants in much akin to how some women present themselves in relation to their spouses (see, for example, Magnusson, 1998). One learns the rules and norms about who are 'insiders' and who are 'outsiders'. They do not challenge the system, but make it known that they know where its boundaries are.

\section{Conflicts about Norms}

Many times when informants were describing successful cases, they mentioned that these cases had taken more time than allowed - than what was acceptable. In other words, they described conflicts about norms they dealt with by breaking the rules of the bureaucracy.

In one of the cases presented as an example of an unsuccessful case, the social worker related a story about one year's work with a girl and her parents at a child and adolescent psychiatric institution. In the beginning, the girl was mute, but today she talks like a waterfall. Yet, the social worker attributed the lack of success with this case to the circumstances involving the referral of the girl back to the local treatment apparatus in her home district.

'They were so clever, they readily took the girl in but they forgot the parents. It was so damned shortsighted not to bring in the parents'.

As the informant defines this situation, it involves in the first place a psychotic girl who is going to be dealt with by a local treatment apparatus for a long time in the foreseeable future. The girl's parents became upset by much of what happened to their daughter and needed very much to confer with someone. But since the local apparatus works only with the girl and not her parents, this made the informant very uneasy. She feared that what she earlier had accomplished would not last.

'The parents were towed along...they felt that I listened to them which was new to them since earlier they felt that no one listened to them'.

At a number of places during the interview, the social worker described the significance of working with parents and how she included them in the cooperative task of focusing on their daughter. Yet, this case is no longer the social worker's. The routines of her institution have required that the girl be transferred back to her home community. The social worker's own institution has dealt with this situation a number of times and has instructed her to leave the case to others. This, however, is her problem and it is reinforced when the girl's parents contact her as they often do. Then the situation becomes problematic for her because she just can't hang up the phone on these parents because the daughter 'belongs to another'. Then, she tells them she:

'has transferred the case and (that) she is very dissatisfied that they the parents have not received assistance. Especially since they are psychiatric patients, because that is what they are. They both received medical pensions'.

When asked whether she had communicated her views to the girl's local treatment apparatus, the social worker answers:

'I have said that many times to them. But when I do that it is like I am telling them something they don't want to know... This is very, very difficult. I become the one who tells them something that is correct'. 
When the father calls and the social worker does not manage to rebuff him totally, she has relayed this to those responsible for the girl, but she feels that 'it is so wrong that he had to contact me'. The social worker feels she has failed to tackle the situation correctly and wishes that she could control her feelings better because they cause 'a split in the system'.

The social worker reports that one reason she reacts this way is because it seems so wasteful that society has used enormous sums of money to help the girl and her parents for more than one year. This resulted in the girl becoming symptom-free:

'And then suddenly there is a bang, a break. It seems very peculiar. I tell the parents we count on them (and that) we give guidance to the local apparatus but they don't want it'.

This informant is caught up in a conflict about norms. This is because she has not managed to solve these problems in a way satisfactory to the local apparatus, the parents and her own institution. Some social workers might have resolved this conflict by rebuffing the parents more than she did. But since she did not do this, the social worker found herself on a tightrope where she tried to make the local authorities understand this case as well as place it ethically above the bureaucratic rules and regulations governing her work. She did not change her practice even after the local authorities went as far as to file a complaint about her actions with the provincial authorities.

The social worker felt that she had not received sufficient guidance with this case, but she assumed full responsibility for not managing to disengage from it. She felt that what happened may have been connected to her own personality. As she interprets it, her desire to help became so strong as to diminish her logical sense and prevent her from using her knowledge effectively. This knowledge, after all, had helped the girl become symptom-free. Therefore, she listened to her own knowledge and dared to move beyond the boundaries of what could be accepted. Her significant other, she reports, is not the bureaucracy of her workplace or of the local treatment apparatus. It is the girl's parents. She views herself as independent and claims not to be worried about whether she is unpopular. This social worker demonstrates what she views as a healthy lack of respect for the norms and presents herself as a rebel.

\section{The Meeting Between Different Discourses}

Thus far in this presentation, I have attempted to examine the everyday activities of social workers along four dimensions: the social worker's position; starting where the client is; rejection and conflicts about norms. All of these dimensions are present in the social workers' own presentations when they described either successful or unsuccessful cases. Moreover, the social workers demonstrated that they analyze cases and their own work in terms of what they called 'the principles of social work'. As an interviewer, I was often deeply impressed by them and felt humbled and full of respect in their presence.

Many of the informants - and especially those newly graduated - reported feeling that their tasks were too large for them to tackle. Often, they wished that they knew more in order to grasp the totalities of the cases with which they worked. They were also much affected by media treatments of social work.

In the beginning of the interviewing, I was very enthused to be able to talk with colleagues about cases. I felt like a circus artist smelling sawdust and greasepaint. Many years had passed since I last saw a client and it was very stimulating for me to interview social workers about their cases.

This did not mean, however, that I did not have ideas different from theirs. Many times I felt that I would not have done what they reported to me. This varied, however, in both positive 
and negative directions. For instance, sometimes I felt that the social worker had not been sufficiently creative or understanding in their work. Yet, at other times, I thought to myself that I never could have managed that or endured that kind of pressure. I was often struck by the feeling that the cases described to me sounded much more difficult than those I remember from my time as a social worker doing clinical work.

Consequently, I was on the whole very much impressed by the high caliber of the work described by the informants. At the same time, however, I felt saddened by their tales of a reality very much different than what was found in contemporary popular accounts of social work - the discourse about social work.

One possibility could have been that the sample of social workers I accessed was comprised of exceptionally competent persons who in no way were representative social workers as a whole. This, however, did not seem probable since there was such a great variation involving years of practice since graduation amongst the informants. I knew that the informants themselves had picked out the successful and unsuccessful cases, so this could have been a factor influencing the narratives they presented during the interviews. Yet, I realized that it would make my study exceptional to characterize the sample as unique and therefore it would be of little use as a measure of how social workers dealt with their everyday activities.

As noted earlier, I saw this analytically as a meeting between two discourses: those in social work and those about social work. 'How', I asked, 'did social workers deal with these? What did they feel about them?' There were many who said they disliked these discourses about social work but that they did not think too much about them. There were no oppositions between the two. Both were omnipresent. The reasons the informants gave for not thinking about these was that if the discourses about social work intruded into their conscious lives this would prevent them from doing good work. In short, in order to be competent practitioners, they had to close their eyes to the many people in society who found few positives and many negatives about the occupational group to which they belonged. Similarly, the informants had to ignore the people who made jokes about them at parties once they declared they were social workers. One informant was married to a lawyer and lawyers 'knew' how social workers were.

It is exceptionally troublesome for those who work as child protection workers. One informant said that: 'it becomes an extra burden' in one's private life. Even if one tries to prevent this work from intruding on one's everyday life, it still manages to exert its influence. As one informant remarked:

'In everyday life I try not to think about it, but it does have consequences'.

One of the informants took up the media's role as a kind of court of appeals. If someone gets a refusal and the media enters the picture, the decision often is repealed. Informants had much to say about the media's role:

'it often gets ridiculous. One is dependent upon Mrs. Hansen who goes with her sob story to the press'.

'The media, too, gets a lot of flak. The hospitals, too. It is not just social work agencies. This will change once the public gets a better idea of what the social work agencies actually do'.

'If you get close to something, you begin to see that it is different than what you have been told. It's probably true that our clients are never going to give us testimonials. We work with those at the grassroots who often can't stand up and speak for themselves'. 
Some informants maintained that much of the criticism directed against social work is justified. They felt that often social workers were not doing good enough work, but it is especially the work of others they criticize. Or, they don't get too engaged when social workers complain at meetings about the poor conditions they work under. They view themselves as part of an occupational market and feel that social work is just one of the things they might wish to work with. To be a furniture maker would provide one with one avenue for other aspects of one's own creativity.

Let me conclude this section with a quote from a young social worker:

'I was very proud when I graduated and became a social worker. The title social worker was something I took great pride in. A wonderful education. But there is something operating in the system so that this feeling doesn't last. There is something about pride we lack. I am very much aware that I have to work with myself and not lose the feeling that I can do good work. I have to keep reading and using the literature, the problem is we don't have time to read much literature'.

\section{Conclusion}

Summarily, this study concerns what takes place within the discipline of social work in comparison to representations about social work. Stated somewhat differently, this account has analyzed discourses within social work in relation to discourse about social work.

In the beginning, I had planned on carrying out a study with the title 'analyses and actions in social work' (Levin 2001). I wished to expand my understanding of actions carried out by social workers as professionals. My goal was to produce a study within the discipline of social work and my aim was to do this without looking at social work from the outside. I was curious about how social workers presented different types of cases when they were allowed to choose for themselves what they felt illustrated good as well as bad cases. I did not wish to end up sorting social workers along a good-bad axis.

What I discovered were different pictures or dimensions of reality produced by social workers. These dimensions I sorted into the following scheme: the positions of social work; starting where the client is; rejection; and norm conflicts. These dimensions represent some important portions of the dialogue in social work. This does not mean, however, that there are no other dimensions found in this discourse. Nevertheless, as this preliminary analysis of the data suggests, these dimensions are those I found worthwhile in examining.

When I started this study, I was under the impression that social work tasks sorted into two categories: bureaucratic casework and therapy. However, what I discovered was that this dichotomy did not hold. Reality was different than what I had supposed and what took place in social work involved a much greater degree of activity overlapping. For example, social workers dealt with many different subjects both when they worked at street-level in frontline services and in secondary services such as hospitals, clinics and other institutional contexts. While social workers in frontline services, for example, were carrying out case management tasks, they also were working both therapeutically and pedagogically practicing with the clients whose cases they were handling. For these and other informants, their practice consisted of these three roles as well as one involving a considerable degree of client care.

Some of these dimensions are perhaps not so surprising as others. The goal has not necessarily been to 'rediscover the wheel' but rather to point out dilemmas connected to the social worker's position. After having worked with these themes for a time and examining in detail my data, one area especially stands out as a central feature of the social worker's everyday activities. This is 
the sheer amount of rejection they must tolerate in the course of their work. Here, the problem is not one involving the fact that clients are seldom going out of their way to compliment social workers acting on their behalf - especially in frontline service agencies. Rather, the problem or problem-complex is one involving those forms of rejection that contribute in many ways to the subordination of social workers. Colleagues from adjacent disciplines play a central role in these processes and are often prime producers of the discourses about social work. These persons often represent 'taken for granted' assumptions about social work as well as the practices related to the power of these kinds of 'knowledges' - power often exercised through vertical downgrading of the status, prestige and practice of social workers.

At the beginning of the study, I felt that would be a correspondence between analysis and action in those cases considered successful by my informants. Conversely, I expected that this connection would be lacking in those presented as unsuccessful. This had been found to be the case in the graduate thesis research conducted by Kronstad (2001) and seemed plausible. Yet, when I began to conduct the interviews and to analyze the data I obtained from them, I could not find this kind of division in my material. ${ }^{612} \mathrm{I}$ realized that one possibility for this divergence was that my informants had not told me about cases they considered extremely unsuccessful. It may be that these demanded another kind of interviewing method to get at the details of such failures. Yet, given the quality of the information that I collected from the informants about both successful and unsuccessful work, it was possible for me to construct a detailed picture of the dilemmas experienced by social workers in the exercise of their professional practice. This understanding produced in me a deep respect and humility for the difficult situations characterizing the social workers everyday activities.

One of the thoughts that struck me at that time was related to an observation about social work made many years ago by Jesse Taft (1939). She declared that the most difficult thing one person can do is to remove a child from its parents. In line with this, I was struck by the fact that social workers are nearly alone in operating in an arena requiring them to navigate and negotiate between society's demands for control and supervision on the one hand and on the other hand its capacity to show solidarity with those in need. This, I found, was especially true of those social workers working in frontline social service agencies and child protection offices.

Coincidental with this, both the informants and I were aware which discourses were being produced about social work. So, I decided to take this observation into account and expand the project accordingly. I began to ask social workers specifically about this discourse. All of them were cognizant of the processes that stigmatized social work and that these created still an additional occupational dilemma with which they had to deal.

The informants in the study were also members of Norwegian society. Thus, they both were aware of and to some extent internalized society's views of social work. However, they believed that on the whole they did a good job. At the same time, they knew that they were viewed negatively by society. And, to some extent, they had integrated both sets of perceptions in their practice. This meant that social workers had a 'double vision' with respect to their practice. This notion, developed in women's studies and especially well elaborated in the work of the feminist therapist, Rachel Hare-Mustin (1991), involves assuming a double gaze of oneself. As earlier noted, this way of looking at oneself using two different lenses is very much a part of life as it is experienced by minorities and other oppressed groups.

What the informants reported in the course of the interviewing is that they must actively select out one set of these perceptions of social work if they were to survive as practitioners. They tell of defining themselves in relation to the norms of the profession as it actually exists in their everyday lives. In so doing, they make a major decision - they quite simply chose not to think about social work in its negative sense. They are very aware of how their profession is 
disparaged, but in respect to both their clients and their own professional pride, they keep this discourse at a safe distance and try not to let it influence them. This can be understood as displacement or as a 'mastering' strategy. Yet, regardless of what the reasons for this are, the discourse chosen by social workers is the one through which they process their experiences into their identities and in this manner create themselves in the interactive process.

With the client as their prime focus, the social workers still have to accept that in some situations that they belong to society's scapegoats. They carry out their work according to the premises laid out for them. And they present themselves within the framing of those rules and the norms governing the types of activities they are to carry out. In solving their dilemmas in this way, they quite simply think and act as if these dilemmas do not exist. In this way, they avoid challenging society's perception both of them and of social work as a discipline. Consequently, the dominant discourse about social work can continue undisturbed by social workers who at the same confirm their identities as subordinate professionals.

In one way, this coincides with another process operating in the same direction. If others who are not social workers gain experiences contradicting popularly held views about social work, these remain outside the realm of normative experience and are regarded as exceptions. Thus, it is possible for the processes stigmatizing social workers and social work to continue unabated. The discourse about social work thus lives its own life without being challenged by the experiential knowledge of individuals.

In the history of social work, there has long been a discussion about the power the social worker possesses in relation to that of the client. My focus here has been on power or lack of power possessed by social work as a discourse in relation to what social workers actually do. And in these arenas, the discourses in social work are in a collision course with the discourses about social work.

\section{Notes:}

1. Discourse may also be defined as practices that systematically create the object they speak about (Foucault 1969: 49) as well as statements and practices sharing common values (Hare-Mustin 1991:64).

2. A notable exception was represented in the Siv Fahlgren's doctoral defense at Umeå University in Sweden.

3. First and foremost, this involves academic social work. The discourses of practical social work are somewhat different, but the academic discourse has influence here as well.

7. It is extremely interesting that psychiatrists who are another group working directly with madness do not experience exclusion to the same degree as social workers. This most probably is due to the fact that they are defined as being within medicine by many in society and that this "gives" psychiatrists the legitimacy enjoyed by this occupational group. However, among the community of physicians, psychiatrists often experience different forms of exclusion.

8. In this connection, the term truth is not meant to refer to what is singularly valid. Rather, this refers to being true in relation to that about which a consensus exists. As Foucault puts it, discourses create the world - they do not reproduce a truthful world out there.

9. The term caseworker can be understood as referring to one who carries out casework and this implies a person functioning in a position of authority. It also can refer to a person who has responsibility for a "client case". In those instances where a person in a non-frontline institution functions as a case worker, the term applies to the person having responsibility for a case.

10. Yet cases involving persons of different ethnic backgrounds were also represented in the "successful" group.

11. It should be emphasized here that I asked about one good and one poor case, not about rejection.

12. These unsuccessful cases will be examined in another article. 


\section{References}

Dewey, John (1925) (1939) Experience and Nature, New York: Holt.

Dahle, Rannveig (1990) Arbeidsdeling - makt - identitet. Doktoravhandling, Institutt for sosialt arbeid, Universitet i Trondheim.

Fahlgren, Siv (1999) Det sociala livets drama och dess manus. Umeå universitet, Institutionen för socialt arbete, nr 29.

Fog, Jette (1982) Om metode, sannhed og solidaritet i Harriet Holter og Ragnvald Kalleberg (eds) Kvalitative metoder i samfunnsforskning, Oslo: Universitetsforlaget.

Førsund Danbolt, Torill (1998) Kunnskap i praksis. Et bidrag til praksisteori i sosialt arbeid, Temaer $i$ sosialt arbeid, 5.

Fook, Jan (2002) Social work: critical theory and practice. London: Sage.

Foucault, Michel (1969/1994) The Archeology of Knowledge. London: Routledge.

Hamran, Torunn (1987) Den tause kunnskapen. Oslo: Universitetsforlaget.

Hare-Mustin, Rachel T. (1991) Sex, lies and headaches: the problem is power. In Goodrich, Thelma Jean (red) Women and Power: Perspectives for Family Therapy. New York: Norton.

Hoel, Karen Colban og Trude Christiane Rønnild (2009) Bevegelser og begrensninger. Analyser av sosialt arbeids kunnskapsgrunnlag gjennom sosialarbeideres fortellinger. Masteroppgave i sosialt arbeid, Høgskolen i Oslo.

Kierkegaard, S. (1859) Synspunktet for min Forfatter-virksomhed: En ligefrem Meddelelse, Rapport til Historien. København: A. E. Reitzels Forlag.

Kronstad, Kari (2001, Hva er sosionomens faglige bidrag i psykiatrisk ungdomsteam? Hovedoppgave i sosialt arbeid, Høgskolen i Oslo.

Levin, Irene (2004), Hva er sosialt arbeid, Oslo: Universitetsforlaget.

Levin, Irene (2001), Sosialt arbeid som kraftfelt, i Jubileumsskrift for avd ØKS, Mons Oppedal (ed.) Høgskolen i Oslo.

Levin, Irene and Trost, Jan (2005) Hverdagsliv og samhandling med et symbolsk interaksjonistisk perspektiv. Bergen: Fagbokforlaget.

Lewin, Kurt, (1944) Constructs in psychology and psychological ecology, Univ. Iowa Stud. Child Welfare, 20-27.

Magnusson, Eva (1998) Vardagens könsinnebörder under förhandling. Umeå universitet.

Mead, George Herbert (1934) Mind, Self and Society. Chicago: University of Chicago Press.

Moseng, Turid (1998) Barnevern - på juristers premisser? En studie av juristers vurdering av barnevernsaker, ISS, Universitetet i Oslo.

Parton, Nigel and Patrick O'Byrne (2000) Constructive social work: Houndsmills, Basingstoke: Macmillan. 
Perlman, Helen (1957) Social Casework, Chicago: The University of Chicago Press.

Payne, Malcolm (1991) Modern Social Work Theory, London: Macmillian.

Rorty, Richard (1997) Kontingens, ironi og solidaritet, Lund: Studentlitteratur.

Saur, Randi (2007). Møte med familievold i sosialtjenesten. Masteroppgave i sosialt arbeid, Høgskolen i Oslo.

Skjervheim, Hans (1976) Deltakar og tilskodar og andre essays. Oslo: Tanum-Nordli.

Smith, Dorothy (1987), The everyday world as problematic. Exploring the relations of ruling. London: Routledge.

Soydan, Haluk (1993) Det sociala arbetets idehistoria. Lund: Studentlitteratur.

Strauss, Anselm L., (1978) Negotiations:varieties, contexts, processes, and social order. San Francisco: Jossey-Bass.

Taft, Jessie (1939) Introduction Journal of Social Work Porcess, vol. III. Pp 1-15)

Thomas, William I. and Thomas, Dorothy S. (1928) The Child in America. New York: Knopf. Østerberg, Dag (1978) Handling og samfunn. Sosiologisk teori i utvalg. Oslo: Pax forlag.

Widerberg, Karin (2001) Historien om et kvalitativt forskningsprosjekt. Oslo:Universitetsforlaget.

Wærnes, Kari (1984) The rationality of caring, Economic and Instrumental Democracy, 5(2):185-211. 